\title{
К ABC izobraževanja odraslih
}

\author{
Daniela Brečko
}

Odlika učbenika $\mathrm{ABC}$ izobraževanja odraslih je, da v njem najdemo natančno to, kar ponuja naslov. Knjiga je izšla pri Andragoškem centru Slovenije in pomeni eno izmed manj številnih del domačih avtorjev, ki se ukvarjajo s pisanjem učbenikov za izobraževanje odraslih. Avtorica Sabina Jelenc nam namreč na približno stotih straneh predstavi poglavitne elemente izobraževanja odraslih. Kratko in jasno opiše koncept vseživljenjskega izobraževanja ter hkrati opredeli in pojasni tudi temeljne strokovne pojme, ki jih najpogosteje srečujemo v literaturi o izobraževanju odraslih.

Postopno nas popelje v svet odraslega človeka in predstavi poglavitne značilnosti posameznih obdobij odraslosti, kajti le tako lahko bolje razumemo zorenje in razvoj zmožnosti za učenje v posameznih življenjskih obdobjih. Svoja spoznanja podkrepi še z rezultati raziskave Odrasli prebivalci Slovenije v izobraževanju iz leta 1989 , ki prikazuje koliko, kaj in kako se odrasli Slovenci učimo.

Posebno pozornost posveti tudi motivom, ki spodbujajo odrasle k učenju, hkrati pa je prepričana, da je treba prav tako dobro kot motive poznati tudi ovire, ki preprečujejo odraslemu, da bi se vključil v izobraževanje.

Učbenik je obogaten $\mathrm{z}$ igrivimi in šaljivimi ilustracijami Simone Bonač, ki skušajo bralca odvrniti od predsodkov, ki so povezani z izobraževanjem in učenjem.

Avtorica podrobno razčleni tudi osebnost strokovnjaka, ki se ukvarja z odraslimi. Ugotavlja, da mora imeti takšen učitelj posebne zmožnosti in osebnostne lastnosti - njegova temeljna naloga pa je spodbujati učenca k neodvisnosti in samostojnemu učenju. Opisuje tudi različne učne metode in oblike izobraževanja odraslih ter primerne učne pripomočke.

Avtorica je napisala učbenik izrazito interdisciplinarno. Delo namreč združuje spoznanja različnih ved, andragogike, psihologije, sociologije, komunikologije itd. To daje učbeniku potrebno širino, s katero ozavešča vse, ki se ukvarjajo z izobraževanjem odraslih, tako da ni pomembna le vsebina izobraževanja, temveč predvsem način prenosa znanja ter odnos med učiteljem ter učencem. Odrasel učenec ima namreč drugačne zahteve, potrebe in hotenja, saj je njegov doživljajski svet precej drugačen, kot je bil v šolskih klopeh.

Na koncu avtorica nameni posebno pozornost tudi tistim odraslim, ki se ne izobražujejo, oziroma tistim, ki se le s težavo odlo-

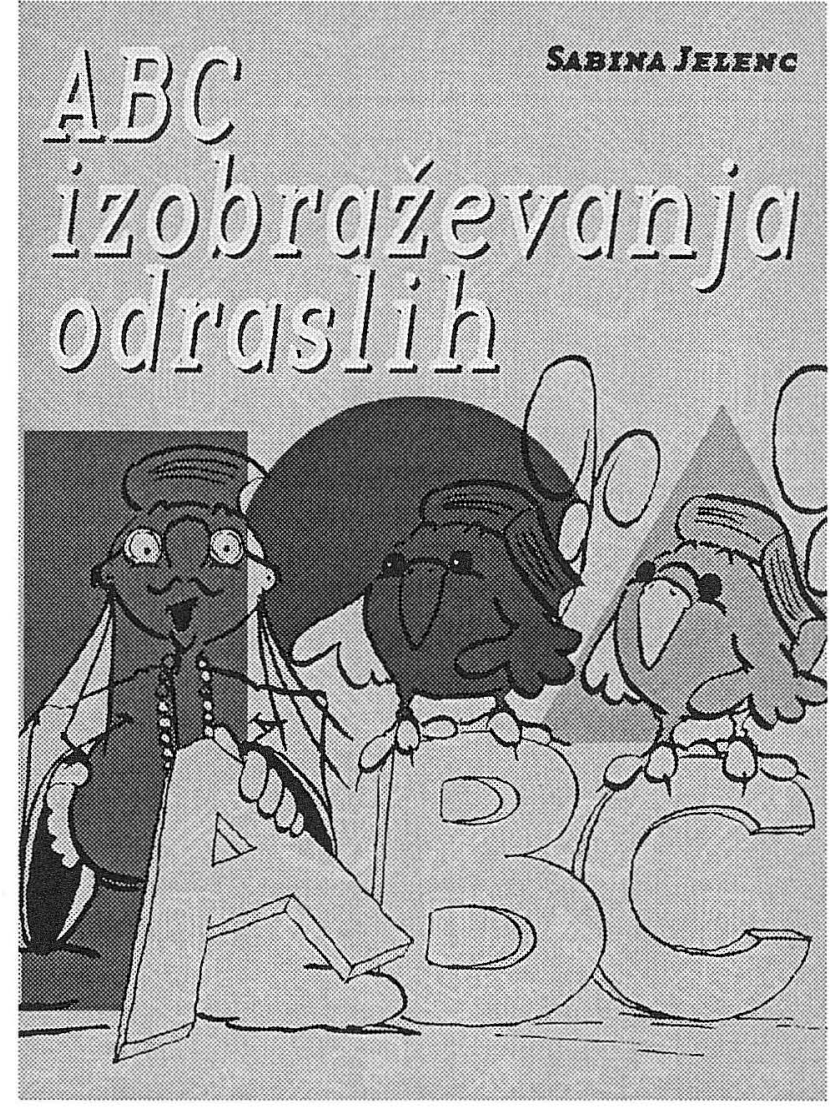

čijo za kakršnokoli obliko izobraževanja. Z opisom poglavitnih značilnosti odraslih, ki se ne želijo izobraževati, daje učiteljem, animatorjem in drugim zadostno podlago za pomoč posameznikom pri premagovanju ovir, na katere so naleteli pri izobraževanju.

Učbenik je odsev prakse, a hkrati tudi dobra teoretična podlaga. Kot takšen je dobrodošel predvsem za manj izkušene učitelje, ki se ukvarjajo z odraslimi, in prijetna novost za vse tiste, ki jih dolgoletno delo $\mathrm{v}$ izobraževalnih institucijah sili $\mathrm{k}$ nenehnemu izpopolnjevanju. Pričujoče delo jim ponuja dovolj izhodišč, da bodo lahko posodobili razmišljanje in zavest o poslanstvu, ki ga opravljajo. 